\title{
MERGER AUDITOR DAN KUALITAS AUDIT: BUKTI EMPIRIS DARI BURSA EFEK INDONESIA
}

\author{
Sansaloni Butar-Butar \\ Fakultas Ekonomi, Universitas Katolik Soegijapranata Semarang \\ sansalonib@yahoo.co.id
}

\begin{abstract}
Merge rof Pricewaterhouse and Coopers \& Lybrands that occurred in 1998 creates PricewaterhouseCoopers as the biggest accounting firm in history. Conceptually and supported by previous empirical result firm size is expected to be positively correlated with audit quality. Large accounting firms have financial ability to improve its auditors skill and can act more independently because major part of their income do not come from one or two clients. They spend huge investment in audit technology as well. However, this positive relationship only applies to environments where punishment is strictly imposed on audit failure. Unlike their counterparts in the United States and Europe, auditors working in Indonesia rarely face legal issues related to the audit assignment. In addition, empirical studies in Indonesia have always classified local auditors as Big $N$ auditors if they affiliate with one of Big $N$ auditors assuming same quality with that of Big $N$ auditors. This assumption does not necessarily hold. Therefore, in the context of Indonesia environtments, this study predicts PricewaterhouseCoopers merger does not affect the quality of the audit. Using abnormal accruals as a proxy for audit quality, the results show that after the merger audit quality has declined significantly.
\end{abstract}

Keywords: audit quality, acrrual abnormal, audit size, big $N$ auditor, audit merger

\section{LATAR BELAKANG}

Literatur terdahulu mengisyaratkan bahwa audit eksternal dapat menurunkan kos keagenan yang muncul akibat dari kesenjangan informasi antara manajer dan pemegang saham (Dopuch dan Simunic 1982) dan semakin tinggi kos keagenan, maka semakin tinggi pula tuntutan terhadap audit yang berkualitas (Watts dan Zimmerman 1986; DeFond 1992). Secara spesifik, audit eksternal menurunkan noise dan bias laporan keuangan (Kinney dan Martin 1994). Namun, keefektifan audit dalam meningkatkan kredibilitas laporan keuangan tergantung dari kualitas auditor (Gul et al., 2010).

DeAngelo (1981) mengisyaratkan bahwa kualitas auditor merupakan fungsi dari ukuran kantor akuntan. Dilihat dalam perspektif ini, merger yang dilakukan oleh Price waterhouse merger dengan Coopers \& Lybrand tahun 1998 merupakan upaya untuk meningkatkan kualitas jasa audit. Palmrose (1988) dan Dye (1993) 
menyatakan bahwa kemampuan keuangan yang kuat (deep pockets) dan pengeluaran besar untuk membangun reputasi menjadi alasan kuat bagi kantor akuntan meningkatkan kualitas audit agar terhindar dari risiko tuntutan hukum. Selain itu, menurut Boone, et al. (2012) kantor akuntan besar lebih independen karena pendapatannya tidak bergantung pada satu klien tertentu. Di samping itu, kantor akuntan besar memiliki kemampuan keuangan yang kuat untuk pelatihan dan investasi pada teknologi audit.

Merger diantara kantor akuntan publik besar menyusutkan jumlah kantor akuntan publik kelompok Big Eight, Big Six dan Big Five (sering disingkat Big N). Skandal keuangan Enron memaksa kantor akuntan Arthur Anderson menyatakan pailit, sehingga kantor akuntan besar kembali menciut menjadi Big Four hingga saat ini. Sulivan (2002) berargumen merger yang dilakukan oleh dua kantor akuntan dapat meningkatkan kualitas audit karena menyatunya spesialis dari kedua kantor akuntan dan lokasi yang saling melengkapi. Kondisi ini akan mendorong efisiensi operasi, menurunkan biaya pemberian jasa audit dan akhirnya meningkatkan kualitas audit.

Walaupun secara konseptual merger kantor akuntan dapat meningkatkan kualitas audit, riset empiris yang menguji korelasi antara kualitas audit dan ukuran kantor akuntan tidak menemukan hasil yang konklusif. Teoh dan Wong (1993) melaporkan bahwa koefisien respon laba perusahaan yang diaudit auditor Big Six lebih tinggi daripada yang bukan Big Six. Hasil yang konsisten juga dilaporkan Becker et al. (1998) dan Francis et al. (1999) yang menemukan tingkat akrual diskresioner yang diaudit oleh auditor Big Five lebih rendah daripada auditor non Big Five. Di sisi lain, hasil-hasil penelitian yang dilakukan di negara yang tuntutan hukum terhadap auditor rendah menemukan hasil yang tidak konsisten. Jheong dan Rho (2004) menguji perbedaan akrual diskresioner perusahaan yang diaudit oleh auditor Big Six dan non Big Six di Korean Stock Exchange dan menemukan bahwa akrual diskresioner kedua kelompok kantor akuntan tersebut tidak menunjukkan perbedaan yang signifikan. Temuan ini mengindikasikan bahwa ukuran kantor akuntan sebagai proksi kualitas audit perlu disesuaikan dengan lingkungan dimana auditor berpoperasi.

Seperti di Korea, kantor akuntan di Indonesia juga jarang mengalami tuntutan hukum dari pihak-pihak yang dirugikan atas pelaporan keuangan perusahaan. Hubungan positif antara ukuran kantor akuntan dan kualitas audit belum tentu teridentifikasi menggunakan perusahaan di Bursa Efek Indonesia. Setidaknya ini tercermin dari riset terdahulu yang menemukan hasil yang tidak konsisten (Herusetya 2009; Dahlan 2009; Sanjaya 2008; Zain 2007). Rendahnya risiko litigasi yang dihadapai oleh auditor di Indonesia menyebabkan dorongan untuk memberikan jasa audit yang berkualitas tidak sama besar seperti rekan mereka di Amerika Serikat dan Eropa. Dengan demikian, pengaruh merger kantor akuntan terhadap kualitas audit menjadi pertanyaan penelitian yang menarik di Indonesia. 
Di samping kondisi hukum di Indonesia yang berbeda dengan negara-negara Barat, hasil riset audit yang tidak konsisten ini mungkin juga disebabkan oleh pengukuran variabel Kantor Akuntan Publik (KAP) Big N yang kurang valid. Semua penelitian di Indonesia mengasumsikan kantor akuntan lokal yang berafiliasi dengan salah satu KAP yang tergolong dalam KAP Big N memiliki kualitas auditor yang sama dengan auditor Big N. Berbeda dengan riset yang dilakukan di Indonesia, riset di AS dan juga Eropa mengelompokkan perusahaan yang diaudit oleh KAP Big N jika benar-benar telah diaudit oleh auditor Big N. Walaupun pemakaian afiliasi dengan salah satu KAP Big N sebagai proksi kualitas audit umum digunakan di Indonesia, patut diduga bahwa kualitas audit yang dihasilkan oleh kantor akuntan yang berafiliasi dengan KAP Big N berbeda dengan kualitas audit yang dihasilkan oleh auditor Big N. Perbedaan skil yang dimiliki KAP afiliasian dengan KAP Big N bisa jadi penyebab hasil penelitian yang gagal menemukan hubungan antara kualitas laporan keuangan dan ukuran perusahaan.

Berdasarkan pemikiran di atas, perlu dipertanyakan kembali apakah merger yang dilakukan oleh kantor akuntan besar memberikan efek yang sama terhadap kualitas audit di negara-negara yang memiliki lingkungan institusional dan hukum yang berbeda seperti Indonesia. Penelitian ini bertujuan untuk menguji pengaruh merger PriceWaterhouse dan Coopers \& Lybrand menjadi PricewaterhouseCoopers terhadap kualitas audit di Indonesia. Penelitian ini berargumen bahwa rendahnya risiko litigasi mengurangi insentif auditor di Indonesia untuk memberikan jasa audit yang berkualitas dan perbedaan keahlian audit antara perusahaan yang berafiliasi dengan Big Four berbeda dengan auditor Big Four. Dengan demikian, kualitas audit sebelum dan setelah merger diprediksi tidak mengalami perubahan yang signifikan.

\section{TINJAUAN LITERATUR}

\section{Manajemen Laba}

Jensen dan Meckling (1976) mengisyaratkan bahwa pemisahan fungsi antara pemilik dan pelaksana perusahaan berpotensi menimbulkan masalah keagenan. Masalah keagenan muncul ketika manajer mendahulukan kepentingan pribadi daripada kepentingan pemegang saham. Salah satu cara untuk mengatasi masalah ini adalah dengan membuat kesepakatan-kesepakatan bersama yang dituangkan dalam kontrak. Angka-angka akuntansi berperan penting dalam menjamin kesepakatan kontrak ditaati oleh manajer (Watts dan Zimmerman 1986). Namun, diskresi yang dimiliki dalam melaporkan angka-angka akuntansi memberikan peluang bagi manajer untuk mempengaruhi pelaporan keuangan.

Healy dan Wahlen (1999) mendiskusikan berbagai peristiwa ekonomi yang mengharuskan manajer menggunakan diskresi dalam pelaporan keuangan. Dalam menentukan biaya depresiasi manajer harus mengestimasi umur ekonomis aset, nilai residual dan metoda depresiasi yang akan digunakan. Manajer juga harus 
menggunakan diskresi ketika menetapkan piutang tak tertagih, menentukan penurunan nilai aset dan jumlah biaya pemeliharaan yang harus dibebankan. Tidak jarang kebijakan akrual yang diadopsi didasari oleh keinginan untuk mempercantik laporan keuangan daripada melaporkan kondisi perusahaan yang sebenarnya. Karena itu, Healy dan Wahlen (1999) mendefinisikan manajemen laba sebagai diskresi manajemen dalam pelaporan keuangan dan dalam penyusunan transaksi yang bertujuan menyesatkan pemegang saham mengenai kinerja ekonomik perusahaan yang sesungguhnya.

Walaupun tidak bisa diamati secara langsung, praktik manajemen laba diyakini telah berlangsung lama. Untuk memberikan bukti empiris berkaitan dengan manajemen laba, para peneliti menggunakan cara-cara yang tidak langsung. Salah satu cara yang telah diterima secara luas adalah dengan mengamati peningkatan atau penurunan akrual diskresioner atau sering juga disebut akrual abnormal. Aktivitas manajemen laba dikatakan terdeteksi bila terjadi perubahan akrual yang tidak normal di seputar peristiwa ekonomi tertentu. Akrual abnormal yang meningkat memberikan indikasi intervensi manajer untuk menaikkan laba. Sebaliknya, penurunan akrual dipandang sebagai usaha sistematis untuk menurunkan laba. Menurut Kaplan (1985) kompensasi manajer yang dikaitkan dengan laba mendorong praktik manajemen laba yang menaikkan laba lebih sering dilakukan daripada yang menurunkan laba. (lihat juga, Becker et al., 1998; DeFond dan Jiambalvo 1994; Kinney dan Martin 1994; Nelson et al. 2002). Walaupun secara teoritis dan didukung beberapa temuan empiris bahwa praktik manajemen laba dapat digunakan sebagai sarana pensignalan (Holthausen 1990; Subramanyam 1996; Louis dan Robinson 2005; Badertscher et al., 2012), sebagian besar riset manajemen laba yang dilakukan selama ini memberikan dukungan yang kuat atas perilaku oportunistik manajer (diantaranya, Healy 1985; Dechow dan Sloan 1991; Defond dan Jiambalvo 1994; Sweeney 1994; DeAngelo dan Skinner 1994; Holthausen et al., 2005; Rangan 1998; Teoh et al. 1998a 1998b; Guidry et al,. 1999; Nelson et al., 2002). Oleh karena itu, audit eksternal yang efektif diharapkan menurunkan kecenderungan manajer memengaruhi laba secara oportunistik (Doupuch dan Simunic 1982; Watts dan Zimmerman 1986; DeFond 1994; Gul et al., 2010).

\section{Kualitas Audit dan Ukuran Auditor}

Teori keagenan mengindikasikan bahwa konflik kepentingan yang terjadi antara agen dan prinsipal bersumber dari kesenjangan informasi (Jensen dan Meckling 1976). Karena itu, untuk meminimalkan kos keagenan perusahaan perlu membentuk mekanisme monitoring agar keselarasan kepentingan antara agen dan prinsipal tercipta. Keberadaan audit eksternal dapat dipandang sebagai salah satu mekanisma monitoring dalam rangka menyelaraskan kepentingan manajer dan pemegang saham (Beatty 1989). Kinney dan Martin (1994) menyatakan bahwa audit eksternal berperan penting dalam membatasi manajemen laba karena dapat menurunkan noise dan bias dalam laporan keuangan. Dengan demikian dapat 
dikatakan bahwa pengauditan meningkatkan kredibilitas laporan keuangan (Dopuch dan Simunic 1982). Namun, peranan audit dalam mengurangi kesenjangan informasi tergantung dari keefektifan auditor dalam melakukan fungsinya (Gul et al., 2010).

Konsep audit yang berkualitas dapat diinterpretasi secara berbeda oleh orang yang berbeda. Bagi pengguna jasa audit, auditor diharapkan dapat mengungkap setiap kesalahan saji material dan kecurangan yang dilakukan oleh manajemen (Epstein dan Geiger 1994). Sementara bagi auditor, tugas seorang auditor adalah untuk memberikan keyakinan yang memadai bahwa laporan keuangan telah disajikan menurut standar pelaporan yang berlaku (Generally Accepted Accounting Principles/GAAP atau International Financial Reporting Standards/IFRS). Menurut DeAngelo (1981) audit yang berkualitas adalah apabila seorang auditor mampu mendeteksi pelanggaran dalam proses pelaporan keuangan dan melaporkan pelanggaran tersebut. Dalam definisi tersebut kualitas audit mengandung dua dimensi (Al-Ajmi 2009). Pertama, auditor harus mampu mendeteksi salah saji material; dan kedua, auditor harus melaporkannya. Palmrose (1988) mendefinisikan kualitas audit sebagai probabilitas bahwa laporan keuangan tidak mengandung kesalahan saji yang material.

Kualitas audit selalu diasosiasikan dengan ukuran kantor akuntan. DeAngelo (1981) berargumen bahwa penghasilan besar yang diperoleh kantor akuntan berukuran besar menempatkan mereka dalam posisi yang lebih rentan dibanding auditor kecil ketika mengalami kegagalan audit. Kompensasi yang harus dibayar jauh lebih besar dibanding kantor akuntan kecil karena pihak yang berperkara berharap mendapatkan uang pengganti yang besar untuk menutupi kerugian investasi. Risiko litigasi yang tinggi dibanding kantor akuntan kecil akan mendorong kantor akuntan besar meningkatkan jasa audit yang mereka tawarkan. Hal yang sama dikemukakan oleh Palmrose (1988) dan Dye (1993). Mereka menyatakan bahwa kemampuan keuangan yang kuat (deep pockets) dan investasi besar yang telah dikeluarkan untuk membangun reputasi menjadi alasan kuat bagi kantor akuntan meningkatkan kualitas audit agar dapat terhindar dari risiko tuntutan hukum. Sebagai tambahan, Boone et al. (2010) menyatakan kantor akuntan besar memberikan jasa audit yang lebih berkualitas dibanding kantor akuntan kecil karena pendapatan kantor akuntan besar tidak bergantung pada satu klien tertentu, sehingga mampu mempertahankan sikap independen dalam mengaudit. Lebih jauh lagi mereka mengatakan bahwa kantor akuntan besar lebih mampu menyediakan dana besar untuk pelatihan dan teknologi audit.

\section{PENGEMBANGAN HIPOTESIS}

\section{Merger dan Kualitas Audit}

Seperti yang telah dibahas dibagian terdahulu, ukuran kantor akuntan selalu dikaitkan dengan kualitas audit. Karena itu, merger di antara kantor akuntan 
merupakan cara yang paling mudah dan rasional untuk meningkatkan kualitas audit. Sebelum merger, PriceWaterhause dan Coopers \& Lybrand merupakan dua kantor akuntan yang memiliki ukuran yang terkecil dibandingkan kantor akuntan lain yang tergabung dalam KAP BigFive (Choi et al., 2013). Namun, ketika merger diantara dua kantor akuntan tersebut terjadi tahun 1998, kantor akuntan baru yang diberi nama PricewaterhouseCoopers menjadi kantor akuntan terbesar sepanjang sejarah dengan lebih dari 40.000 pegawai yang bekerja di 11.000 kantor di seluruh dunia dan total pendapatan mencapai 13 Milyar Dollar (Ding dan Jia 2012).

Riset terdahulu yang menguji korelasi antara ukuran kantor akuntan dan kualitas audit umumnya dilakukan dengan membandingkan kantor akuntan Big N dan kantor akuntan non Big N. Jarang sekali riset yang menguji kualitas audit diantara kantor akuntan yang tergolong dalam Big $\mathrm{N}$ atau di antara Big $\mathrm{N}$ dengan kantor akuntan besar di luar Big N. Hal ini mungkin didorong oleh keinginan peneliti untuk mendapatkan perbandingan yang kontras, sehingga semakin tinggi kemungkinannya untuk mendapatkan hasil yang signifikan. Berkaitan dengan merger, riset terdahulu lebih terfokus pada perbedaan upah audit (audit fee) sebelum dan setelah merger (misalnya, Menon dan Williams 2001 dan Wolk et al., 2001) daripada perbedaan kualitas audit (mislanya, Ding dan Jia 2012). Minimnya riset empiris yang menguji perbedaan kualitas audit di antara kantor akuntan yang tergabung dalam Big $\mathrm{N}$ menyulitkan untuk membangun argumen yang mendukung pengaruh positif merger kantor akuntan terhadap kualitas audit. Walaupun beberapa studi empiris seperti Blouin et al., (2007), Cahan dan Zhang (2006) dan Krishnan (2007) menemukan peningkatan kualitas audit setelah Arthur Anderson bangkrut, Choi et al. (2013) menyatakan bahwa secara kualitatif penelitian-penelitian tersebut berbeda dengan merger auditor dan hasil-hasil temuan tersebut mungkin disebabkan oleh pemberlakukan Sarbanes Oxley (SOX) daripada peningkatan kualitas audit.

Studi Ding dan Jia (2012) merupakan salah satu riset yang menguji pengaruh merger PricewaterhouseCoopers terhadap kualitas audit di Inggris Raya (United Kingdom). Dalam penelitian ini mereka menggunakan kualitas laba dan akrual abnormal (diskresioner) sebagai proksi kualitas audit. Menggunakan sampel perusahaan publik yang di audit oleh kantor akuntan Big X dan Non Big X, mereka membandingkan kualitas laba diantara kedua kelompok kantor akuntan dengan menggunakan akrual abnormal absolut dan relevansi nilai laba. Dalam penelitian tersebut auditor Big X mengacu pada auditor yang masuk kelompok Big 8 (19851989), Big 6 (1990-1997), Big 5 (1998-2002) dan Big 4 (setelah 2002). Hasil pengujian menunjukkan bahwa akrual diskresioner absolut perusahaan yang menjadi klien auditor Big X mengalami penurunan dibandingkan perusahaan yang menjadi klien auditor non Big X dan laba perusahaan yang menjadi klien auditor Big X memiliki korelasi yang kuat dengan return saham. Ini mengindikasikan bahwa kualitas laba mengalami peningkatan pasca merger. Sementara, hasil pengujian untuk kelompok perusahaan yang menjadi klien non Big X menunjukkan bahwa kualitas 
laba tidak mengalami peningkatan yang signifikan. Dengan kata lain, kualitas audit auditor non Big $\mathrm{X}$ tidak mengalami peningkatan setelah merger PricewaterhauseCoopers. Secara keseluruhan hasil pengujian menunjukkan bahwa merger meningkatkan kualitas audit.

Perlu dicatat bahwa penelitian Ding dan Jia (2012) menggunakan data dari pasar modal dimana auditor menghadapi risiko litigasi yang tinggi bila memberikan audit dengan kualitas rendah. Menjadi pertanyaan yang menarik apakah peningkatan kualitas audit yang sama dapat teridentifikasi di negara yang memiliki lingkungan institusional dan hukum yang berbeda. Walaupun tidak menguji pengaruh merger, studi Jeong dan Rho (2004) mengisyaratkan bahwa korelasi antara ukuran kantor akuntan dan kualitas audit perlu dimaknai secara berbeda pada lingkungan institusional dan hukum yang berbeda. Mereka menguji pengaruh kualitas audit antara auditor Big Six dan non Big Six menggunakan data perusahaan dari pasar modal Korea. Mereka berargumen bahwa apabila auditor beroperasi pada lingkungan yang tidak menerapkan aturan yang tegas kepada auditor ketika melakukan kegagalan audit dan ketika mekanisma monitoring lainnya tidak berjalan efektif untuk mengendalikan manajemen laba, auditor mungkin memilih untuk tidak bekerja secara profesional dan memberikan jasa audit yang berkualitas rendah. Menurut Ding dan Jia, sangat jarang sekali auditor dijatuhi hukuman di Korea dan mekansime monitoring untuk mengendalikan perilaku oportunistik auditor juga belum berjalan efektif. Di Korea, auditor yang dipilih biasanya memiliki hubungan personal yang erat dengan perusahaan sehingga sulit untuk mempertahankan sikap independen. Lebih jauh lagi dikatakan bahwa audit independen yang dilakukan oleh auditor eskternal bukan menjadi faktor penting untuk mendapatkan tambahan modal di Korea. Manajer perusahaan menganggap pengeluaran untuk biaya audit sebagai sesuatu yang sebenarnya tidak perlu dan hanya menambah kos dalam melakukan bisnis.

Apa yang terjadi di Korea merupakan fenomena yang biasa terjadi di Indonesia. Di samping penegakan aturan yang lemah, investor di Indonesia juga hampir tidak pernah membawa kasus manipulasi keuangan hingga ke pengadilan. Ambil contoh kasus Bank Lippo yang sempat menarik perhatian publik tahun 2002. Walaupun hasil investigasi Badan Pengawas Pasar Modal dan Lembaga Keuangan (Bapepam-LK) menemukan indikasi kuat bahwa direksi perusahaan Bank Lippo terlibat dalam praktik manajemen laba untuk menutupi kerugian sebesar 1,273 Triliun, tidak satupun kelompok investor atau pihak lainnya yang membawa kasus ini ke pengadilan. Melihat kesamaan lingkungan sosial dan hukum di Indonesia dan Korea dalam kaitannya dengan audit eksternal, dapat diekspektasi bahwa dorongan auditor untuk melaksanakan pengauditan secara efektif dan berkualitas tidak sekuat rekan mereka di Amerika Serikat atau Eropa. Artinya, tuntutan untuk memberikan jasa audit yang berkualitas bukan suatu keharusan tetapi lebih pada pilihan. Auditor bisa memilih untuk bekerja profesional pada suatu waktu dan tidak melakukannya 
pada waktu yang lain. Jika ekspektasi ini berlaku maka tidak heran jika hasil riset kualitas audit terdahulu menemukan hasil yang tidak konsisten (Herusetya 2009; Dahlan 2009; Sanjaya 2008; Zain 2007). Rendahnya risiko litigasi menyebabkan auditor tidak bekerja konsisten dalam menjalankan fungsi audit.

Tampaknya argumen konseptual yang dikemukakan oleh DeAngelo (1981), Palmrose (1988), Dye (1993) dan peneliti lainnya hanya berlaku pada negara-negara yang memberikan sanksi tegas terhadap pelanggaran audit. Di negara-negara yang penegakan aturan audit masih rendah, argumen konseptual mendukung hipotesis KAP Big N mewakili audit yang berkualitas perlu dipertanyakan; khususnya di Indonesia. Di samping perbedaan lingkungan institusional dan hukum, ketidakkonsistenan hasil riset yang menguji hubungan antara kualitas audit dan ukuran kantor yang dilakukan di Indonesia mungkin juga disebabkan oleh asumsi yang menyetarakan kualitas auditor lokal yang berafiliasi dengan salah satu KAP Big $\mathrm{N}$ dengan auditor yang berasal dari KAP Big N itu sendiri. Seperti yang sudah diketahui, kantor akuntan asing tidak diijinkan mendirikan cabang di Indonesia, kecuali bekerja sama dengan KAP lokal yang sering disebut dengan KAP afiliasi Big N. Umumnya penelitian empiris di Indonesia mengelompokkan perusahaan yang menjadi klien kantor akuntan lokal yang berafiliasi dengan KAP Big N sebagai KAP Big $\mathrm{N}$ dan kantor akuntan lokal yang tidak berafiliasi dengan KAP Big N sebagai non Big N. Pemisahan seperti ini mengandung kelemahan karena belum tentu kualitas audit yang dihasilkan oleh kantor akuntan yang berafiliasi dengan KAP Big N setara dengan kualitas audit yang dihasilkan oleh KAP Big N itu sendiri. Perlu penelitian kualitatif untuk menggali lebih banyak informasi tentang perbedaan pengetahun dan keahlian antara KAP lokal yang berafiliasi dengan Big N dan KAP lokal yang tidak berafiliasi. Patut dicurigai bahwa kualitas yang dimiliki oleh auditor KAP yang berafiliasi dengan KAP Big $\mathrm{N}$ tidak sama dengan auditor KAP Big $\mathrm{N}$ itu sendiri. Setidaknya ini tercermin dari beberapa hasil penelitian yang gagal menemukan hubungan yang konsisten antara kualitas laporan keuangan dan KAP Big N.

Berdasarkan argumen di atas, penelitian ini memprediksi bahwa merger yang dilakukan oleh kantor akuntan besar memberikan efek yang berbeda terhadap kualitas audit di negara-negara yang memiliki lingkungan institusional dan hukum yang berbeda seperti Indonesia. Lebih spesifik, penelitian ini berargumen bahwa rendahnya risiko litigasi terhadap auditor yang tidak menjalankan fungsi audit secara profesional dan bertanggung jawab menurunkan insentif auditor lokal untuk meningkatkan kualitas audit sekalipun auditor tersebut berafiliasi dengan PricewaterhouseCoopers. Perbedaan kualitas audit antara auditor lokal yang berafiliasi dengan Big Four dan auditor yang bekerja langsung di KAP Big Four menyebabkan merger yang dilakukan oleh dua kantor akuntan besar Pricewaterhouse dan Coopers \& Lybrand tidak membawa pengaruh signifikan terhadap kualitas audit. Pengaruh merger PricewaterhouseCoopers dan kualitas audit dinyatakan dalam hipotesis berikut ini: 
H1: Dengan mempertimbangkan perbedaan lingkungan institusional dan hukum di Indonesia, kualitas audit PricewaterhouseCoopers tidak mengalami peningkatan pasca merger.

\section{METODA PENELITIAN}

\section{Data dan Pengambilan Sampel}

Penelitian ini menggunakan data sekunder yang bersumber dari: (1) laporan tahunan perusahaan yang dapat diakses melalui situs resmi Bursa Efek Indonesia dengan alamat www.bei.co.id; (2) Indonesian Capital Market Directory (ICMD) edisi 1995-2002 yang diterbitkan oleh Institute for Economic and Financial Research; (3) Pusat Database Pasar Modal Fakultas Ekonomi dan Bisnis Universitas Katolik Soegijapranata.

Pemilihan sampel dilakukan berdasarkan kriteria: (1) sampel adalah perusahaan manufaktur yang tercatat di Bursa Efek Indonesia secara berturut-turut dari tahun 1995 hingga tahun 2002 yang merupakan klien dari KAP lokal yang berafiliasi dengan KAP PriceWaterhouse, KAP Coopers \& Lybrands dan KAP hasil merger Pricewaterhouse Coopers. Alasan menggunakan perusahaan manufaktur adalah untuk mendapatkan data yang homogen. Perbedaan karakteristik perusahaan dapat mengaburkan makna variabel yang hendak diukur. Misalnya, pengukuran akrual diskresioner menggunakan model Jones modifikasian membutuhkan data perubahan piutang. Piutang pada perusahaan manufaktur memiliki makna yang berbeda dengan piutang pada perusahaan keuangan dan asuransi; (2) perusahaan yang digunakan sebagai sampel menyediakan secara lengkap data-data yang dibutuhkan untuk mengukur variabel-variabel penelitian. Berdasarkan kriteria pemilihan sampel di atas, jumlah observasi yang terkumpul selama tahun penelitian adalah 94 tahun perusahaan, dengan rincian sebagai berikut: tahun 1995 dan 1996 masing-masing 18 perusahaan, tahun 1997 berjumlah 22 perusahaan, tahun 1999 berjumlah 11 perusahaan, tahun 2000 berjumlah tujuh perusahaan, tahun 2001 berjumlah sepuluh perusahaan dan tahun 2002 berjumlah delapan perusahaan. Tahun 1998 (saat merger terjadi) sengaja dikeluarkan dari sampel karena tahun tersebut digunakan sebagai cut off untuk membandingkan akrual diskresioner sebelum dan setelah merger PricewaterhouseCoopers.

\section{Model Pengujian Hipotesis}

Penelitian ini menguji perbedaan tingkat akrual abnormal (diskresioner) absolut tahun 1995-1997 dan 1999-2002. Tahun 1998 merupakan tahun peristiwa merger sehingga tidak termasuk dalam periode penelitian. Kualitas audit tercermin dari tingkat akrual abnormal. Seperti yang telah dijelaskan sebelumnya, akrual abnormal yang merupakan proksi manajemen laba dapat disalah gunakan manajer untuk menaikkan laba. Akibatnya, laporan laba-rugi tidak menggambarkan realitas yang ada. Auditor yang menjalankan tugasnya dengan baik diekspektasi dapat 
menurunkan tingkat akrual abnormal. Dengan kata lain, audit yang berkualitas dapat menurunkan manajemen laba. Variabel dummy digunakan untuk menguji perbedaan akrual diskresioner sebelum dan setelah merger. Untuk menghindari pengaruh variabel lain yang dapat menurunkan validitas hasil penelitian, empat variabel kontrol ditambahkan ke dalam model regresi, yaitu ukuran perusahaan (size), tingkat utang (leverage), profitabilitas (Return on Asset/ROA) dan arus kas operasi (Cash From Operation/CFO) Persamaan berikut ini digunakan untuk menguji hipotesis:

\begin{tabular}{|c|c|c|}
\hline \multicolumn{3}{|l|}{ Keterangan: } \\
\hline ABS_AKRU $U_{i, t}$ & $=$ & $\begin{array}{l}\text { Akrual abnormal absolut diperoleh dari nilai residual model Ball } \\
\text { dan Shivakumar, model Jones modifikasian atau model Kasznik } \\
\text { yang diestimasi secara pool cross-sectional }\end{array}$ \\
\hline Merger $_{i, t}$ & $=$ & $\begin{array}{l}\text { variabel dummy, } 0 \text { jika observasi berasal dari tahun 1995-1997 } \\
\text { dan } 1 \text { jika berasal dari tahun 1999-2002 }\end{array}$ \\
\hline $\mathrm{DER}_{\mathrm{i}, \mathrm{t}}$ & $=$ & Rasio utang terhadap ekuitas aset pada awal tahun \\
\hline $\mathrm{ROA}_{\mathrm{i}, \mathrm{t}}$ & $=$ & Rasio laba bersih terhadap aset awal tahun \\
\hline Size $_{i, t}$ & $=$ & $\begin{array}{l}\text { Ukuran perusahaan dihitung dari ln nilai buku aset pada awal } \\
\text { tahun }\end{array}$ \\
\hline $\mathrm{CFO}_{\mathrm{i}, \mathrm{t}}$ & $=$ & $\begin{array}{l}\text { arus kas operasi yang diperoleh secara langsung dari laporan } \\
\text { arus kas }\end{array}$ \\
\hline
\end{tabular}

\section{Pengukuran Variabel}

a) Merger

Peristiwa merger PricewaterhouseCoopers tahun 1998 diukur menggunakan variabel dummy. Variabel ini bernilai satu jika perusahan sampel merupakan klien KAP lokal yang berafiliasi dengan PricewaterhouseCoopers selama tahun 1999-2002 dan bernilai nol jika perusahan sampel merupakan klien KAP lokal yang berafiliasi dengan KAP PriceWaterhouse atau Coopers \& Lybrands selama periode 1995-1997. Selama tahun 1995-1997 KAP lokal yang berafiliasi dengan KAP PriceWaterhouse adalah KAP Hadi Sutanto dan rekan. Sementara yang berafiliasi dengan KAP Coopers dan Lybrands adalah KAP Hans Tuanakotta \& Mustofa dan Rekan. Setelah merger, KAP lokal yang berafiliasi dengan PricewaterhouseCoopers tahun 1999-2002 adalah KAP Haryanto dan Rekan.

b) Akrual Abnormal Absolut

Seperti yang telah dijelaskan, akrual abnormal (akrual diskesioner) merupakan proksi yang digunakan untuk menilai kualitas audit. Pada awalnya, para peneliti banyak menggunakan model regresi yang diperkenalkan oleh Jones (1991) untuk memisahkan komponen diskresioner (abnormal) dan non-diskresioner (normal) dari total akrual secara time-series. Dalam model tersebut, akrual diskresioner merupakan fungsi dari perubahan pendapatan dan tingkat peralatan, pabrik dan properti. Model ini mengasumsikan bahwa modal kerja perusahaan sepenuhnya berasal dari penjualan dan akrual yang berasal dari depresiasi peralatan, pabrik dan properti (Bernard dan Skinner 1996). Model ini mengalami beberapa revisi di kemudian hari, diantaranya dilakukan oleh Ball dan Shivakumar (2006), 
Kasznik (1999) dan Dechow et al. (1995). Dalam penelitian ini, model revisi Ball dan Shivakumar (2006) digunakan untuk menampilkan statistik deskriptif. Namun, model Kasznik (1999) dan Dechow et al. (1995) tetap digunakan sebagai robustness check. Berikut ini adalah formula yang digunakan untuk mengestimasi akrual abnormal:

1) Model Ball dan Shivakumar (2006)

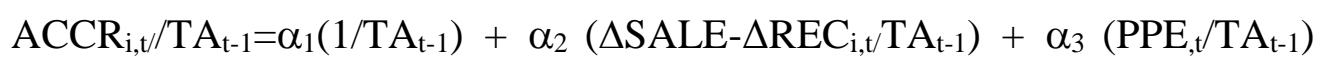

$$
\begin{aligned}
& +\alpha_{4}\left(\mathrm{CFOt} / \mathrm{TA}_{\mathrm{t}-1}\right)+\alpha_{5} \mathrm{D} \_\mathrm{CFO} \mathrm{t}_{\mathrm{t}}+\alpha_{6}\left(\mathrm{CFOt} / \mathrm{TA}_{\mathrm{t}-1}\right) * \mathrm{D}_{-} \mathrm{CFO}_{\mathrm{t}}+ \\
& \mathrm{e}_{\mathrm{t}}
\end{aligned}
$$

Dalam model di atas, $\mathrm{ACCR}_{\mathrm{t}}$ adalah akrual total pada tahun $\mathrm{t}$ yang diperoleh dari selisih antara laba sebelum pos-pos ekstraordiner dan operasi yang tidak berlanjut (discontinued operation) dan arus kas (CFO), $\mathrm{TA}_{\mathrm{i}, \mathrm{t}-1}$ merupakan aset total tahun $\mathrm{t}, \triangle \mathrm{SALE}_{\mathrm{i}, \mathrm{t}}$ merupakan perubahan penjualan pada tahun $\mathrm{t}, \mathrm{D} \_\mathrm{CFO}_{\mathrm{t}}$ merupakan variabel dummy tahun $\mathrm{t}$, satu jika arus kas operasi bernilai positif dan 0 jika sebaliknya, dan $\mathrm{PPE}_{\mathrm{i}, \mathrm{t}}$ merupakan peralatan, pabrik dan properti tahun t. Model ini diestimasi secara pool cross-sectional untuk seluruh periode pengamatan. Akrual abnormal merupakan nilai residual yang diperoleh dari hasil regresi. Selanjutnya, nilai akrual abnormal ditransformasi ke nilai absolut dan dijadikan sebagai proksi kualitas audit.

2) Model Jones modifikasian

$\mathrm{ACCR}_{\mathrm{i}, \mathrm{t} / \mathrm{TA}} \mathrm{T}_{\mathrm{i}, \mathrm{-}-1}=\alpha_{1}\left(1 / \mathrm{TA}_{\mathrm{i}, \mathrm{t}-1}\right)+\alpha_{2}\left(\Delta \mathrm{SALE}_{\mathrm{i}, \mathrm{t} / \mathrm{TA}} \mathrm{i}_{\mathrm{t}-\mathrm{-}-1}\right)+\alpha_{3}\left(\mathrm{PPE}_{\mathrm{i}, \mathrm{t}} / \mathrm{TA}_{\mathrm{i}, \mathrm{t}-1}\right)+\mathrm{e}_{\mathrm{i}, \mathrm{t} . . .}$

Seluruh variabel dalam model ini didefinisikan dan diukur dengan cara yang sama seperti dalam model Ball dan Shivakumar (2006).

3) Formula model Kasznik (1999):

$$
\begin{aligned}
& \mathrm{ACCR}_{\mathrm{i}, \mathrm{t} / \mathrm{TA}} \mathrm{TA}_{\mathrm{t}-\mathrm{l}}=\alpha_{1}\left(1 / \mathrm{TA}_{\mathrm{i}, \mathrm{t}-1}\right)+\alpha_{2}\left(\mathrm{SALE}_{\mathrm{i}, \mathrm{t} /} \mathrm{TA}_{\mathrm{i}, \mathrm{t}-1}\right)+\alpha_{3}\left(\mathrm{PPE}_{\mathrm{i}, \mathrm{t}} / \mathrm{TA}_{\mathrm{i}, \mathrm{t}-1}\right) \\
& +\alpha 4\left(\Delta \mathrm{CFOe}_{\mathrm{i}, \mathrm{t}}\right)+\mathrm{e}_{\mathrm{i}, \mathrm{t}}
\end{aligned}
$$

Seluruh variabel dalam model ini didefinisikan dan diukur dengan cara yang sama seperti dalam model Ball dan Shivakumar (2006).

c) Laba

Variabel laba yang digunakan dalam penelitian ini adalah laba sebelum pos-pos ekstraordiner dan discontinued operation. Hal ini bertujuan untuk meminimalkan pengaruh-pengaruh transaksi yang tidak normal yang dapat menurunkan validitas penghitungan variabel-variabel akrual.

d) Arus Kas Operasi

Variabel ini diperoleh dari laporan arus kas perusahaan dan digunakan untuk memisahkan komponen akrual dari laba yang dilaporkan. Akrual total perusahaan merupakan selisih antara laba dan arus kas operasi. 
e) Variabel Kontrol

Ada empat variabel kontrol yang digunakan dalam penelitian ini: tingkat utang (leverage), ukuran perusahaan, profitabilitas dan arus kas operasi. Keempat variabel kontrol ini merefleksikan tiga hipotesis besar yang diajukan oleh Watts and Zimmerman (1986): debt covenant hypothesis, bonus plan hypothesis dan political cost hypothesis. Hasil-hasil riset manajemen laba terdahulu menemukan leverage berhubungan positif dengan manajemen laba (Sweeney 1994; DeFond dan Jiambalvo 1994) dan ukuran perusahaan berhubungan negatif dengan manajemen laba (Jones 1991). Di samping mewakili hipotesis paket bonus, profitabilitas (ROA) dan arus kas operasi (CFO) dimasukkan ke dalam model regresi untuk mengendalikan pengaruh perbedaan kinerja terhadap akrual diskresioner yang diestimasi menggunakan model Jones atau variasinya (Kothari et al., 2005)

\section{HASIL DAN ANALISIS}

\section{Statistik Deskriptif}

Setelah melewati penyeleksian sampel, total observasi yang tersedia berjumlah 94 tahun perusahaan. Dari jumlah ini, beberapa observasi untuk masingmasing model harus dihilangkan agar memenuhi asumsi normalitas. Rinciannya adalah sebagai berikut: sebanyak sepuluh observasi (10,63 persen) dihilangkan untuk model Ball dan Shivakumar, empat observasi (4 persen) dihilangkan untuk model Kasznik dan sepuluh observasi (10,63 persen) dihilangkan untuk model Jones modifikasian. Tabel 1 menyajikan statistik deskriptif variabel-variabel yang digunakan dalam pengujian hipotesis periode 1995-1997 dan 1999-2002. Variabel akrual abnormal absolut dideflasi dengan aset total awal tahun. Karena itu, variabel yang tersaji untuk masing-masing model mencerminkan persentase terhadap aset total awal tahun.

Dari Tabel 1 (Panel A) dapat dilihat bahwa akrual abnormal absolut yang merupakan proksi kualitas audit mengalami peningkatan untuk ketiga model yang digunakan. Akrual abnormal absolut model Ball dan Shivakumar mengalami peningkatan dari rerata 4 persen pada tahun 1995-1997 menjadi 6 persen tahun 19992002 dan perbedaan tersebut signifikan secara statistis pada level 10 persen (satu sisi). Sementara, Akrual abnormal absolut model Kasznik mengalami peningkatan dari rerata 4 persen pada tahun 1995-1997 menjadi 5 persen tahun 1999-2002 signifikan secara statistis pada level 10 persen (satu sisi). Untuk model Jones modifikasian, akrual abnormal absolut meningkat dari 10 persen pada tahun 19951997 menjadi 12 persen tahun 1999-2002. Namun perbedaan tersebut tidak signifikan secara statistis. Secara keseluruhan, temuan ini menjadi bukti awal bahwa setelah merger PricewaterhouseCoopers kualitas audit tidak mengalami peningkatan. 
Bahkan setelah merger ada kecenderungan kualitas audit menurun yang ditandai dengan meningkatnya manajemen laba (akrual abnormal absolut).

Tabel 1

Kualitas Audit dan Karakteristik Perusahaan

Panel A

\begin{tabular}{|c|c|c|c|c|c|c|c|c|c|}
\hline \multirow[b]{2}{*}{ Variabel } & \multicolumn{4}{|c|}{ Periode 1995-1997 $(\mathrm{N}=50)$} & \multicolumn{4}{|c|}{ Periode 1999-2002 $(\mathrm{N}=34)$} & \multirow[b]{2}{*}{$\begin{array}{r}\text { Uji Beda } \\
\text { (satu sisi) }\end{array}$} \\
\hline & Min & Maks & $\begin{array}{l}\text { Rata- } \\
\text { rata }\end{array}$ & $\begin{array}{l}\text { Dev. } \\
\text { Std }\end{array}$ & Min & Maks & $\begin{array}{l}\text { Rata- } \\
\text { rata }\end{array}$ & $\begin{array}{l}\text { Dev. } \\
\text { Std }\end{array}$ & \\
\hline $\begin{array}{l}\text { ABS_AKRUAL } \\
\text { (Kznk) }\end{array}$ & 0,00 & 0,15 & 0,04 & 0,03 & 0,00 & 0,13 & 0,05 & 0,03 & 0,062 \\
\hline $\begin{array}{l}\text { ABS_AKRUAL } \\
\text { (Jones) }\end{array}$ & 0,00 & 0,91 & 0,10 & 0,13 & 0,14 & 0,49 & 0,12 & 0,11 & 0,161 \\
\hline $\begin{array}{l}\text { ABS_AKRUAL } \\
\text { (B\&Shv) }\end{array}$ & 0,00 & 0,14 & 0,04 & 0,04 & 0,01 & 0,14 & 0,06 & 0,04 & 0,053 \\
\hline DER & 0,16 & 7,05 & 1,39 & 1,49 & 0,35 & 8,58 & 1,66 & 1,91 & 0,249 \\
\hline SIZE & 18,99 & 28,54 & 25,39 & 2,41 & 25,61 & 30,94 & 27,78 & 1,29 & 0,000 \\
\hline ROA & $-0,26$ & 0,22 & 0,04 & 0,07 & $-0,03$ & 0,38 & 0,11 & 0,10 & 0,000 \\
\hline $\mathrm{CFO}$ & $-0,26$ & 0,25 & 0,03 & 0,11 & $-0,79$ & 0,77 & 0,11 & 0,26 & 0,023 \\
\hline
\end{tabular}

Panel B.

\begin{tabular}{llll}
\hline Dummy & Frekuensi & Persen & Persen Kumulatif \\
\hline 0 & 50 & 59,5 & 59,5 \\
1 & 34 & 40,5 & 100 \\
Total & 84 & 100 & \\
\hline
\end{tabular}

Kecuali tingkat utang Debt to Equity Ratio (DER) semua variabel kontrol mengalami peningkatan yang signifikan. Tabel 1 (Panel A) memperlihatkan bahwa profitabilitas perusahaan Return On Asset (ROA) mengalami peningkatan sepanjang periode penelitian, dari 4 persen pada periode 1995-1997 menjadi 11 persen pada periode 1999-2002 dan peningkatan tersebut signifikan secara statistis pada level kurang dari 1 persen (satu sisi). Sementara arus kas operasi Cash From Operation (CFO) meningkat dari 3 persen pada periode 1995-1997 menjadi 11 persen pada periode 1999-2002 dan peningkatan tersebut signifikan secara statistis pada level 5 persen (satu sisi). Ukuran perusahaan (size) juga mengalami peningkatan yang signifikan pada level kurang dari 1 persen. Secara keseluruhan, hasil ini mengindikasikan bahwa setelah merger semakin banyak perusahaan besar dan yang memiliki prospek yang baik memilih PricewaterhouseCoopers sebagai auditor mereka. Namun perlu dicatat, tingginya profitabilitas bisa juga disebabkan aktivitas manajemen laba yang tidak terdeteksi oleh auditor. Peningkatan $R O A$, size dan $C F O$ selama periode penelitian semakin memperkuat dukungan untuk memasukkannya sebagai variabel kontrol. Sementara itu, dari Panel B dapat dilihat sampel perusahaan periode sebelum merger lebih banyak (59,5 persen) dibandingkan setelahnya (40,5 persen). 


\section{Korelasi Pearson}

Dari Tabel 2 dapat dilihat bahwa ketiga model estimasi akrual berkorelasi signifikan pada level 1 persen. Korelasi yang tinggi ini mengindikasikan bahwa model Ball dan Shivakumar, model Kasznik dan model Jones modifikasian memiliki keandalan yang hampir sama dalam mendeteksi manajemen laba. Namun, korelasi akrual abnormal ketiga model tersebut dengan variabel merger tidak menunjukkan kecenderungan yang sama. Akrual abnormal absolut model Kasznik satu-satunya yang berkorelasi signifikan dengan merger. Dua model lainnya tidak menunjukkan korelasi yang signifikan. Perlu dicatat bahwa variabel merger merupakan variabel indikator (dummy). Jadi korelasi antara akrual abnormal absolut yang jenis datanya rasio dan merger yang berjenis nominal tidak memiliki makna yang berarti.

Tabel 2

Matriks Korelasi

\begin{tabular}{llllccccc}
\hline & Ball_Shiva & Kasznik & Jones & Merger & DER & Size & ROA & CFO \\
\hline \hline Ball_Shiva & & 1 & & & & & & \\
Kasznik & $0,471^{* *}$ & & 1 & & & & & \\
Jones & $0,499^{* *}$ & $0,636^{* *}$ & \multicolumn{1}{c}{1} & & & & & \\
Merger & 0,206 & $0,223^{*}$ & 0,105 & 1 & & & & \\
DER & 0,209 & 0,016 & $0,704^{* *}$ & $-0,059$ & 1 & & & \\
Size & 0,079 & 0,14 & 0,14 & $0,495^{* *}$ & 0,147 & 1 & & \\
ROA & $-0,144$ & 0,001 & $-0,194$ & $0,419^{* *}$ & $-0,289^{* *}$ &, $232^{*}$ & 1 \\
CFO & $-0,262^{*}$ & $-0,327^{* *}$ & $-0,742^{* *}$ & 0,151 & $-0,522^{* *}$ & 0,110 & $0,284^{* *}$ & 1 \\
\hline
\end{tabular}

$* *$ Correlation is significant at the 0.01 level (2-tailed).

*Correlation is significant at the 0.05 level (2-tailed).

Korelasi variabel kontrol dengan akrual abnormal absolut ketiga model menunjukkan hasil yang konsisten. Variabel $C F O$ berkorelasi kuat (pada level 1\%) dengan akrual abnormal absolut ketiga model. Sementara, tidak satupun akrual abnormal absolut ketiga model berkorelasi signifikan dengan ROA dan size. Varibel kontrol Debt to Equity Ratio (DER) hanya berkorelasi dengan model Jones yang sudah dimodifikasi.

\section{Hasil Pengujian}

Hipotesis H1 memprediksi bahwa perbedaan lingkungan institusional dan ekonomi di Indonesia memperlemah hubungan antara kualitas audit dan ukuran perusahaan, sehingga merger PricewaterhouseCoopers tidak membawa pengaruh signifikan terhadap kualitas audit. Hipotesis ini diuji menggunakan tiga model estimasi akrual abnormal (diskresioner) yang berbeda: model 1 menggunakan formula yang diusulkan oleh Ball dan Shivakumar, model 2 menggunakan formula Kasznik dan model 3 adalah model Jones modifikasian. Menggunakan Analisis regresi, pengaruh merger PricewaterhouseCoopers dapat di lihat pada Tabel 3. 
Dari Tabel 3 dapat dilihat bahwa koefisien merger memiliki arah positif untuk tiap-tiap model dan signifikan secara statistik pada level 1 persen (model 2 dan model 3) dan 5 persen (model 1). Arah positif menunjukkan bahwa manajemen laba yang diukur dengan akrual abnormal absolut pada periode 1999-2002 lebih tinggi daripada periode 1995-1997. Hasil ini mengindikasikan bahwa setelah PriceWaterhouse dan Lybrands \& Coopers sepakat melakukan merger tahun 1998 membentuk PricewaterhouseCoopers, manajemen laba mengalami peningkatan. Hasil ini bertentangan dengan argumen konseptual dan juga tidak konsisten dengan hasil penelitian terdahulu. Secara konseptual, kantor akuntan yang lebih besar seharusnya menawarkan jasa audit yang lebih berkualitas karena alasan-alasan yang telah dibahas sebelumnya. Walaupun tidak sesuai dengan yang diprediksi H1, temuan ini mempertegas dugaan bahwa faktor lingkungan institusional dan hukum turut berperan kuat dalam memengaruhi kualitas audit. Sementara itu, dari ketiga variabel kontrol, hanya $C F O$ yang menunjukkan pengaruh yang konsisten terhadap akrual abnormal absolut untuk ketiga model. Pengaruh $D E R$ terhadap akrual abnormal absolut hanya teridentifikasi pada model 3 dan pengaruh $R O A$ teridentifiksi secara lemah pada model 1 .

Tabel 3

Regresi Akrual Abnormal Absolut terhadap Merger dan Variabel Kontrol

\begin{tabular}{lrrrrrr}
\hline & \multicolumn{2}{c}{ Model 1 } & \multicolumn{2}{c}{ Model 2 } & \multicolumn{2}{c}{ Model 3 } \\
& Koef. B & \multicolumn{1}{c}{$\boldsymbol{p}$-value } & Koef. B & $\boldsymbol{p}$-value & \multicolumn{1}{c}{ Koef. $\boldsymbol{\beta}$} & \multicolumn{1}{c}{$\boldsymbol{p}$-value } \\
\hline Konstanta & 0,046 & 0,361 & 0,031 & 0,748 & 0,018 & 0,845 \\
Merger & 0,024 & 0,018 & 0,049 & 0,005 & 0,050 & 0,009 \\
DER & 0,001 & 0,691 & $-0,006$ & 0,220 & 0,007 & 0,000 \\
Size & $-0,000$ & 0,999 & $-0,002$ & 0,590 & 0,002 & 0,507 \\
Roa & $-0,086$ & 0,097 & $-0,136$ & 0,128 & $-0,010$ & 0,905 \\
Cfo & $-0,051$ & 0,023 & $-0,086$ & 0,021 & $-0,360$ & 0,000 \\
& & & & & & \\
N & 84 & & 90 & & & 84 \\
Adj. R2 & 0,098 & & 0,106 & & & 0,717 \\
\hline
\end{tabular}

Keterangan:

ABS-AKRUAL $(B \quad \&=$ akrual abnormal dari model Ball dan Shivakumar, model Jones Shv, Kasznik, Jones) $\quad$ modifikasian dan model Kasznik yang diestimasi secara poolcrosssectional

Merger = variabel dummy, yang bernilai 0 jika obervasi berasal dari tahun 19951997 dan 1 jika berasal dari tahun 1999-2002

DER $\quad=$ rasio utang terhadap equitas

ROA = rasio laba bersih sebelum item-item ekstraordiner terhadap aset total

SIZE $\quad=\log$ aset yang merepresentasikan ukuran perusahaan

$\mathrm{CFO}=$ Arus kas operasi setelah dideflasi aset total

\section{Pengujian Sensitivitas}

Krisis moneter yang melanda Indonesia tahun 1997-1999 membawa dampak yang luas terhadap kinerja pasar modal saat itu. Untuk menghindari pengaruh 
sistematis krisis keuangan yang terjadi terhadap hasil penelitian, maka pengujian tambahan dilakukan dengan menghilangkan observasi yang berasal dari tahun 1997 dan 1999. Hasil regresi dapat dilihat pada Tabel 4.

Tabel 4

Regresi Kualitas Audit Terhadap Merger dan Variabel Kontrol

\begin{tabular}{lrrrrrr}
\hline & \multicolumn{2}{c}{ Model 1 } & \multicolumn{2}{c}{ Model 2 } & \multicolumn{2}{c}{ Model 3 } \\
& Koef. B & p-value & Koef. B & p-value & \multicolumn{1}{c}{ Koef. $\beta$} & \multicolumn{1}{c}{$p$-value } \\
\hline Konstanta & 0,066 & 0,275 & 0,074 & 1,390 & 0,011 & 0,917 \\
Merger & 0,030 & 0,010 & 0,028 & 0,008 & 0,072 & 0,001 \\
DER & $-0,001$ & 0,809 & 0,000 & 0,964 & $-0,003$ & 0,734 \\
Size & $-0,001$ & 0,797 & $-0,001$ & 0,545 & 0,003 & 0,429 \\
Roa & $-0,106$ & 0,142 & $-0,102$ & 0,112 & $-0,140$ & 0,244 \\
Cfo & $-0,060$ & 0,026 & $-0,022$ & 0,337 & $-0,391$ & 0,000 \\
N & 59 & & 59 & & & 57 \\
Adj. R2 & 0,123 & & 0,077 & & & 0,573 \\
\hline
\end{tabular}

Secara kualitatif, hasil yang ditampilkan dalam Tabel 4 tidak berbeda dengan Tabel 3. Koefisien merger (dummy) untuk ketiga model memiliki arah positif dan signifikan secara statistis pada level 1 persen. Seperti sebelumnya, temuan ini mengindikasikan bahwa setelah merger, kualitas audit PricewaterhouseCoopers mengalami penurunan.

Temuan dalam penelitian ini tidak hanya bertentangan dengan hasil-hasil penelitian terdahulu tetapi juga bertolak belakang dengan argumen konseptual yang diisyaratkan dalam literatur terdahulu (DeAngelo 1981; Palmrose 1988; Davidson dan Neu 1993; Dye 1993). Seperti yang telah dijelaskan pada bagian sebelumnya, kantor akuntan besar selalu dikaitkan dengan kualitas audit yang lebih baik dibandingkan kantor akuntan yang lebih kecil karena kemampuan keuangannya yang besar (deep pockets), keinginan menjaga reputasi dan investasi besar dalam teknologi audit. Menggunakan data pasar modal Inggris Raya, Ding dan Jia (2012) menemukan bahwa pasca merger, kualitas audit PricewaterhouseCoopers mengalami peningkatan. Namun harus diingat bahwa Ding dan Jia (2012) menggunakan laporan keuangan klien PricewaterhouseCoopers yang beroperasi di negara yang menerapkan aturan ketat terhadap kegagalan audit (audit failure). Jeong dan Rho (2004) menggunakan data dari pasar modal Korea gagal mengidentifikasi korelasi positif tersebut. Menurut mereka, hubungan positif antara ukuran perusahaan dan kualitas audit tidak ditemukan di Korea karena risiko litigasi rendah, mekanisma monitoring lain tidak berjalan dan pemilihan auditor berdasarkan hubugan personal.

Lingkungan institusional di Indonesia tidak berbeda jauh dengan Korea. Karena itu, tidak mengejutkan jika korelasi positif ukuran kantor akuntan dan kualitas audit juga tidak berhasil teridentifikasi dalam penelitian ini. Namun yang menimbulkan pertanyaan adalah mengapa kualitas audit justru memburuk setelah merger PricewaterhauseCoopers? Untuk saat ini, peneliti tidak bisa memberikan 
penjelasan yang memuaskan. Perlu penelitian lanjutan sebelum melakukan inferensi; misalnya menggunakan relevansi nilai sebagai pengukur kualitas audit seperti yang dilakukan Ding dan Jia (2012). Namun, hasil ini memperkuat dugaan bahwa asumsi yang menyetarakan kualitas auditor lokal yang berafiliasi dengan salah satu KAP Big $\mathrm{N}$ dengan auditor yang bekerja pada KAP Big $\mathrm{N}$ merupakan suatu kekeliruan. Singkatnya, hasil yang kontra intuitif yang ditemukan dalam penelitian ini menimbulkan pertanyaan tentang: (1) penggunaan akrual abnormal sebagai proksi kualitas audit dan 2) validitas pengelompokan auditor Big $\mathrm{N}$ dan non Big $\mathrm{N}$ berdasarkan hubungan afiliasi kantor akuntan lokal dengan Big N.

\section{SIMPULAN, KETERBATASAN DAN SARAN}

\section{Simpulan}

Penelitian ini berargumen bahwa perbedaan lingkungan institusional dan hukum antara Indonesia dan negara-negara Barat dapat mempengaruhi hubungan antara ukuran perusahaan dan kualitas audit. Dalam lingkungan yang memiliki risiko litigasi yang rendah seperti di Indonesia, auditor tidak memiliki dorongan yang kuat untuk memberi jasa audit yang berkualitas. Karena itu, penelitian ini memprediksi merger dua kantor akuntan besar Pricewaterhouse dan Coopers \& Lybrand tidak membawa pengaruh signifikan terhadap kualitas audit.

Serangkaian pengujian yang dilakukan menggunakan analisis regresi menunjukkan bahwa pasca merger, kualitas KAP yang berafiliasi dengan PricewaterhouseCoopers mengalami penurunan. Temuan ini kontra intuitif karena bertentangan dengan argumen konseptual maupun hasil-hasil riset sebelumnya.

\section{Keterbatasan dan Saran}

Sebelum inferensi diambil, ada beberapa keterbatasan penelitian ini yang perlu dipertimbangkan.

1. Penelitian ini menggunakan akrual abnormal (diskresioner) untuk mencerminkan kualitas audit. Masalahnya adalah manajemen laba tidak sama dengan manipulasi laba. Standar pengauditan tidak mengharuskan auditor untuk mendeteksi manajemen laba. Oleh karena itu, penelitian berikutnya perlu menggunakan proksi lain seperti relevansi nilai laba, upah audit dan jam kerja audit sebagai proksi kualitas audit.

2. Sampel perusahaan yang digunakan dalam periode 1995-1997 berbeda dengan periode 1999-2002. Idealnya, sampel perusahaan dalam kedua periode tersebut sama untuk mengurangi variasi yang disebabkan perbedaan karakteristik perusahaan. 


\section{DAFTAR PUSTAKA}

Al-Ajmi, J. 2009. Advances in accounting, incorporating. Advances in International Accounting. Vol.25: 64-74.

Badertscher, B. A. 2011. Over valuation and the choice of alternative earnings management mechanism. The Accounting Review. Vol.86 No.5: 1491-1518.

Ball, R., dan L. Shivakumar. 2005. Earnings quality in UK private firms: Comparative loss recognition timeliness. Journal of Accounting and Economics. Vol.39: 83-128.

Beatty, R. 1989. Auditor reputation and the pricing of initial public offerings. Accounting Review. Vol.64: 693-709.

Beatty, A., S. Chamberlain, dan J. Magliolo. 1995. Managing financial reports of commercial banks: The influence of taxes, regulatory capital and earnings. Journal of accounting research. Vol.33: 231-261.

Becker, C. L., M. Defond, J. Jiambalvo, dan K. Subramanyam. 1998. The effect of audit quality on earnings management. Contemporary Accounting Research. Vol.15: 1-24.

Bernard, V. L., dan D. J. Skinner. 1996. What motivates manager's choice of discretionary accruals? Journal of Accounting Research. Vol.22: 313-325.

Blouin, J., B. M. Grein, dan B. R. Rountree. 2007. An analysis of forced auditor change: The case of former Arthur Andersen clients. The Accounting Review. Vol.82: 621-650.

Boone, J., I. Khurana, dan K. Raman. 2012. Audit market concentration and auditor tolerance of earnings management. Contemporary Accounting Research. Vol.29 No.4: 1171-1203.

Cahan, S. F., dan W. Zhang. 2006. After enron: Auditor conservatism and exAndersen clients. The Accounting Review.Vol.81 No.1: 49-82.

Choi, J. H., S. Kim, dan K. K. Raman. 2013. Did the 1998 merger of price waterhouse and coopers \& lybrand increase audit quality? A firm and officelevel analysis. Working Paper.

DeAngelo, L. 1981. Auditor size and audit quality. Journal of Accounting and Economics. Vol.3: 183-199.

DeAngelo, L., H. DeAngelo, dan D. Skinner. 1994. Accounting choice in troubled companies. Journal of Accounting and Economics. Vol.17: 113-143.

Ding, R., dan Y. Jia. 2012. Auditor mergers, audit quality and audit fees: Evidence from the PricewaterhouseCoopers merger in the UK. Journal of Accounting and Public Policy. Vol.31 No.1: 69-85. 
Epstein, M. J., dan M. A. Geiger. 1994. Investor views of audit assurance: Recent evidence of the expectation gap. Journal of Accountancy. Vol.177: 60-66.

Francis, J. R., E. L. Maydew, dan H. C. Sparks. 1999. The role of Big 6 auditors in the credible reporting of accruals. Auditing: A Journal of Practice \& Theory. Vol.18 No.2: 17-34.

Dahlan, M. 2009. Analisis hubungan antara kualitas audit dengan diskresioner akrual dan kebebasan auditor. Padjadjaran University: Department of Accounting.

Davidson, R. A., dan D. Neu. 1993. A note on the association between audit firm size an audit quality. Contemporary Accounting Research. Vol.9: 479-488.

Dechow, P., dan J. Jiambalvo. 1993. Factors related to auditor-client disagreement over income-increasing accounting method. Contemporary Accounting Research. Vol.9 (spring): 415-431.

Dechow, P., dan R. Sloan. 1991. Executive incentives and the horizon problem: an empirical investigation. Journal of Accounting and Economics. Vol.14: 5189.

Sloan, R., dan A. Sweeney. 1995. Detecting earnings management. The Accounting Review. Vol.70: 193-225.

DeFond, M. L. 1994. Debt covenant violation and manipulation of accruals. Journal of Accounting \& Economics. Vol.17.

DeFond, M. L., dan J. Jiambalvo. 1993. Factors related to auditor-client disagreement over income-increasing accounting method. Contemporary Accounting Research. Vol.9 (spring): 415-431.

Dopuch, N., dan D. Simunic. 1982. The competition in auditing an assessment. Fourth Symposium on Auditing Research. Urbana University of Illinois: 401450 .

Dye, R. A. 1993. Auditing standards, legal liability and auditor wealth. Journal of Political Economy. Vol.101: 887-914.

Eldenburg, L. G., K. A. Gunny., K. W. Hee, dan N. Soderstom. 2011. Earnings management using real activities: evidence from nonprofits hospitals. The Accounting Review.Vol.86 No.5: 1605-1630.

Guidri, F., J. L. Andrew, dan R. Steve. 1999. Earnings-based bonus plans and earnings management by business-unit managers. Journal of Accounting and Economics: 113-142.

Gul, F. A., J. B. Kim, dan A. Qiu. 2010. Ownership concentration, foreign shareholding, audit quality, and stock price synchronicity: Evidence from China. Journal of Financial Economics. Vol.95: 425-442. 
Healy, P. M. 1985. The effect of bonus schemes on accounting decisions. Journal of Accounting \& Economics. Vol.7.

Healy, P. M., dan J. M. Wahlen. 1999. A review of earnings management literature and its implication for standard setting. Accounting Horizons. Vol.13: 365383.

Herusetya, A. 2009. Pengaruh ukuran auditor dan spesialisasi auditor terhadap kualitas laba. Jurnal Akuntansi dan Keuangan Indonesia. Vol.6 No.1.

Holthausen, R. W. 1981. Evidence on the effect of bond covenants and management compensation contracts on the choice of accounting techniques: The case of the depreciation switch-back. Journal of Accounting and Economics. Vol.3: 73-109.

.1990. Accounting method choice: opportunistic behaviour, efficient contracting, and information perspectives. Journal of Accounting and Economics Vol.12: 207-218.

Jensen, M. C., dan W. H. Meckling. 1976. Theory of the Firm: Managerial behavior, agency costs and ownership structure. Journal of Financial Economics: 305360.

Jheong, S. W., dan J. Rho. 2004. Big Six auditors and audit quality: The Korean evidence. The International Journal of Accounting. Vol.39: 175-196.

Kasznik, R. 1999. On the association between voluntary disclosure and earnings management. Journal of Accounting Research. Vol.37: 57-81.

Khurana, I. K., dan K. K. Raman. 2004. Litigation risk and the financial reporting credibility of Big 4 versus non-Big 4 audits: Evidence from Anglo-American countries. The Accounting Review. Vol.79 No.2: 473-495.

Kinney Jr, W. R., dan R. D. Martin. 1994. Does auditing reduce bias in financial reporting? A Review of audit-related adjustments studies. Auditing: A Journal of Practice \& Theory. Vol.13 (Spring): 151-156.

Kothari, S., A. Leone., dan C. Wasley. 2005. Performance matched discretionary accrual measures. Journal of Accounting and Economics. Vol.39: 163-197.

Jones, J. 1991. Earnings management during import relief investigation. Journal of Accounting Research. Vol.29: 193-228.

Krishnan, G. V. 2007. Did earnings conservatism increase for former Andersen clients? Journal of Accounting, Auditing \& Finance. Vol.27 No.1: 141-163.

Kaplan, R. S. 1985. Comments on Paul Healy: Evidence on the effect of bonus schemes on accounting procedure and accrual decisions. Journal of Accounting and Economics. Vol.7: 109-113. 
Louis, H., dan D. Robinson. 2005. Do managers credibly use accruals to signal vs private information? Evidence from the pricing of discretionary accruals around stock splits. Journal of Accounting \& Economics. Vol.39: 361-380.

Menon, K., dan D. D. Williams. 2001. Long term trends in audit fees. Auditing: A Journal of Practice and Theory. Vol.20: 115-136.

Nelson, M., J. Elliott, dan R. Tarpley. 2002. Evidence from auditors about managers' and auditors' earnings management decisions. The Accounting Review 77 (Supplement): 175-202.

Palmrose, Z. 1988. Analysis of auditor litigation and audit service quality. The Accounting Review. Vol.63: 55-73.

Rangan, S. 1998. Earnings management and the performance of seasoned equity offerings. Journal of Financial Economics. Vol.50: 101-122.

Richardson, S. A., R. G. Sloan., M. T. Soliman, dan I. Tuna. 2005. Accrual reliability, earnings persistence and Stock price. Journal of Accounting and Economics. Vol.39: 437-485.

Sanjaya, S. P. I. 2008. Auditor Eksernal, Komite Audit, dan Manajemen Laba. Jurnal Riset Akuntansi Indonesia. Vol.11 No.1: 97-116.

Schipper, K. 1989. Commentary on earnings management. Accounting Horizons (December): 91-102.

Subramayam, K. R. 1996. The pricing of discretionary accruals. Journal of Accounting and Economics. Vol.22: 249-281.

Sullivan, M. W. 2002. The effect of Big Eight accounting firm mergers on the market for audit services. Journal of Law and Economics. Vol.45: 375-399.

Sweeney, A. P. 1994. Debt-covenant violations and manager's accounting responses. Journal of Accounting and Economics (May): 281-308.

Teoh, S. H., dan T. J. Wong. 1993. Percived auditor quality and the earnings response coefficients. The Accounting Review. Vol.68 (April): 346-366.

Teoh, S. H., I. Welch, dan T. J. Wong. 1998a. Earnings management and the under performance of seasoned equity offerings. Journal of Financial Economics. Vol.50: 63-99.

Teoh, S. H., I. Welch, dan T. J. Wong. 1998b. Earnings management and the under performance of initial public offerings. Journal of Finance. Vol.53: 19351974.

Wahlen, J. 1994. The nature of information in commercial loan loss disclosures. The Accounting Review. Vol.69: 455-478. 
Wolk, C. M., S. E. Michelson, dan C. W. Wootton. 2001. Auditor concentration and market share in the US: 1988-1999 a descriptive note. British Accounting Review. Vol.33: 157-174.

Watts, R., dan J. Zimmerman. 1986. Positive accounting theory. Engelwood Cliffs, NJ: Prentice Hall. 